\title{
An Assessment of Media Coverage of Anti-Corruption Campaigns by the Buhari Administation in 2016: A Study of the Nation and Daily Trust Newspaper
}

Lemdi Edmond* and Fredrick Wilson

Department of Mass Communication, University of Maiduguri, Nigeria

\begin{abstract}
This study assessed mass media coverage of anti-corruption in Nigeria: a study of Muhammadu Buhari civilian administration (2015-2019). The objectives of this study are: to determine the frequency of reports on corruption in The Nation and Daily Trust newspaper; to determine the direction in which issues of corruption are reported in the newspapers; to examine the prominence given to issues of corruption in the selected dailies. 48 editions of The Nation and Daily Trust newspapers July 1, 2016 to December 31, 2016 were analyzed using purposive sampling and systematic sampling technique in selecting the two newspapers. The study adopted the Agenda Setting Theory and its components: framing and priming as the theoretical framework. The two selected Nigerian newspapers; The Nation and Daily Trust were purposively selected to form the population, 48 editions ( 24 for each newspaper title) were selected for analysis using the systematic sampling technique. The researcher performed a 1 -in- 5 systematic sample out of the 240 editions out of which 48 editions were drawn. Coding sheet was used as research instrument for effective data collection to show the frequency of reports, direction of reports and prominence to obtain reliable and valid information, and to ensure prompt analysis of the data that will be collected. Three content categories were developed by the researcher for proper classification of items, they are Indictments/Prosecution, Recovery and Arrests. The Units of analysis for this study were News, Features, Editorials and Letters to the Editor. The researcher encountered challenges during the course of the study which necessitated careful adjustments to be made in order to contain them while bearing in mind the objectives of the study and ethical principles of research. Challenges encountered include the lack of access to a few copies of The Nation newspaper editions that fall within the sample drawn hence the subsequent day's edition (next day's edition) was used for analysis. Data were presented using tables and simple percentages. Data collected were addressed based on the objectives of the study and research questions. A total of 409 items were reported by the selected newspapers within the study period. Individually, The Nation reported 233 items while Daily Trust reported 176 items on corruption. The study found that issues on corruption were reported frequently by the selected newspapers; reports on corruption were mainly found in the inside pages; and issues of corruption reported by selected dailies were mostly positive. The mass media cover issues of corruption in Nigeria adequately but need to give prominence to them. The study recommends that the mass media should engage in in-depth coverage and investigative journalism to uncover and expose corruption and not just rely on reporting happenings only.
\end{abstract}

Keywords: Newspaper; Analysis; Media; Economic

\section{Introduction}

The destructive impact of corruption upon nations throughout the world is acknowledged. Corruption is perhaps the most important factor that is impeding the accelerated socio-economic transformation of developing or Less Developing Countries (LDCs) of the world. In fact, it is recognized by development scholars that the level of reduction in corruption has a very direct link to the level of economic development of nations in the world.

The media and civil society groups have been identified as important weapon to fight the scourge of corruption worldwide. Nigeria has become a country where the victory of wrong over right is celebrated, falsehood over the truth and supremacy of personal irresponsibility over fundamental values. It is a country where propagating policies that fail to value human life and humanity thrives but cherishes material possession, power and pleasures. It is a place where men and women of honor, experience, credibility and self-consciousness have been cut in their prime for daring to talk. It is a place where crooks are protected by the powers-that-be and leaders are not determined by the citizenries through votes. Without doubt, Nigeria is a breeding habitat for corruption.

Officially, corruption in Nigeria has evolved from the petty to the grand, from occasional and uncommon phenomenon to an endemic, widespread and organized feature of society. Nigerians regard public office as the primary means to gain access to unlimited wealth. Public office opens the "widest avenue" for public officers to loot, embezzle, defraud, swindle, peculate, misappropriate, rob, cheat, thief and steal public resources with impunity [1-3].

Arian [4] asserts that corruption is Nigeria's biggest single problem. It has not only weary public trust in government, but it has cost the government and the people of Nigeria poverty and underdevelopment. A report by Nigeria's Economic and Financial Crimes Commission in 2005 revealed that the country's successive governments stole and misused about 400 billion US dollars during the last four decades of the $20^{\text {th }}$ century [5]. Corruption in Nigeria led to squandering of the enormous resources available to the nation thus becoming a factor

*Corresponding author: Lemdi Edmond, Department of Mass Communication University of Maiduguri, Nigeria, Tel: +2347037626884; E-mail: lemdigreat@gmail.com

Received May 21, 2018; Accepted July 04, 2018; Published July 11, 2018

Citation: Edmond L, Wilson F (2018) An Assessment of Media Coverage of Anti-Corruption Campaigns by the Buhari Administation in 2016: A Study of the Nation and Daily Trust Newspaper. J Mass Communicat Journalism 8: 376 . doi: 10.4172/2165-7912.1000376

Copyright: $\odot 2018$ Edmond L, et al. This is an open-access article distributed under the terms of the Creative Commons Attribution License, which permits unrestricted use, distribution, and reproduction in any medium, provided the original author and source are credited. 
in the country's ailing economy, crumbling infrastructure, clanging poverty, pauperized citizenry, moral regression, disunity, violence and crime [6].

Corruption thrives in the Nigerian society to an extent that it is seen as a normal way of life. Public officers in government establishments have continuously practiced all sort of corrupt activities while discharging their duties hence causing rot and decay to the system thereby holding service delivery at stake.

Private organizations and individuals are not left out in this menace. Corruption has eaten deep into the fabric of the Nigerian society hence the need for a complete overhaul of the system as well as attitudinal change by the entire populace to ensure a better society where good governance and accountability thrive. The mass media as agents of information dissemination are major stakeholders in the fight against corruption. They are responsible for educating informing and enlightening the public on the effects of corruption in the society and ways to eradicate it.

To the common man in the society, one must be ready to sacrifice something (cash or kind) to gain favors or consideration for services due to him ordinarily as due process permits. Public officers will solicit or are lured into accepting gratification for services they were employed and paid to render. This is injurious to the quality of services the society deserves to enjoy. This however is no particular to just public institutions but extends to the private sector and the educational sector. Bribes are elicited or given as a pre-condition to be served contracts, admissions or placements into choice courses of study.

The media that are ideally positioned to check these excesses are not spared from corrupt practices. Gratification and rewards have become conditions for media access and prominence. News makers often use the media for building good image for themselves and their organizations. The concept of 'PR-news' has increasingly become popular in the Nigerian media landscape. Journalists prefer to attend press briefings with juicy packages at the end which influences the tune of reporting. The media therefore tends to become prejudiced and publish editorialized reports. What becomes of their gullible audiences who consume such contents written to favour government rather than check their overall performance?

Media play key roles in investigating allegations of impropriety in public affairs expose corruption and corrupt practices [7]. These roles become even more important when existing political institutions are weak and inefficient in ensuring accountability of public servants World Bank, (1997). Credible media, therefore, exercise strong influence over the public and play an important part in revealing improper and unfair administrative actions and corruption [7].

According to Coronel [8], the mass media as main expression of public opinion have long been recognized as having social and constitutional responsibilities in monitoring government, exposing its excesses and ensuring that governments are accountable to the governed. The usefulness of the media as active participants in the responsibility to rid society of corruption and promote good governance is undeniably established and guaranteed in most constitutions of nations. Section 22 of the 1999 Constitution of the Federal Republic of Nigeria states that:

The press, radio, television and other agencies of the mass media shall at all times be free to uphold the fundamental objectives contained in this chapter and uphold the responsibility and accountability of the government to the people (FRN, 1999).
This constitutional role requires the media as a social institution to be responsive to social problems and needs, to serve the political system by providing information, discussion, and debate, and act as watchdogs over government [8]. This suggests that the press can strengthen democratic institutions by conscientiously and effectively investigating systematic corruption as stated by Center for Democracy and Governance [9] that now holds Nigeria society hostage [6].

Similarly, Stiglitz 2002, remarks, "there has long been recognition that on their own, governments and their leaders do not have the initiative to disclose let alone disseminate information that is contrary to their interest". But free speech and a free press not only make abuses of government powers less likely, they also enhance the likelihood that basic needs will be met Stapenhurst [7]. Accordingly, media can act as a force against corruption in ways that are both tangible and intangible [7]. Tangible ways media can curb corruption take a variety of forms. Most spectacular among them is when corrupt bureaucrats or public office holders are impeached, prosecuted or forced to resign after their misdeeds are made public [7].

According to Gambo [10], the fundamental objectives and directive principle of state policy outlined in the Constitutional provisions of Section 22 quoted above encapsulates the political objective i.e., unity and faith, peace and progress. This basically fosters national integration through facilitating the free movement of goods and services across the country, inter-marriages, securing citizens' rights and promotes formation of associations across religious, ethnic and sectional barriers.

The economic objectives include harnessing the resources of the nation to promote national prosperity and a vibrant economy. This revolves around securing maximum welfare, happiness and freedom to citizens on grounds of social justice, and equal opportunities for all while the social objectives are based on the ideals of freedom, equality and justice which will provide citizens adequate means of livelihood, promotion of family life, safety and protection of citizens from exploitation. The development and prosperity of the nation and the happiness of the Nigerian citizens therefore hinges on these constitutional provisions.

Gambo [10] asserts that the media have a duty to ensure that all actions of government and government officials remain consistent with these objectives. The media help to create and maintain a sense of nationhood, and undertake developmental tasks through education and building political stability, help in the formation of public opinion and creates forum for public discussions and as well serve as watchdogs on government to prevent all forms of abuses. Pye 1967 cited in Gujbawu 2002 succinctly observed:

Even in the most weak and unstable country, the mass media retain to some degree their basic function: that of serving as inspector-general to the entire political system so as to provide the necessary public criticism to ensure some degree of political integrity among the power holders.

In Nigeria, the most spectacular manifestations of the potentials of the media potential in curbing corruption has been the forced resignations of Mallam Salihu Buhari, Evans Enwerem, Chuba Okadigbo, Adolphus Wabara, and more recently, Patricia Ette, Adenike Grange and others for scandals of forgeries, falsifications and contract scams. Githongo 1999 also relates the role the independent Kenyan press played in the firing of a Minister of Health, Mr. Donald Kimutai in 1996.

However, the assumption of office as a democratically elected 
president by Muhammadu Buhari signaled a new era for Nigeria. Known for his dislike for corruption, he enjoyed popular support from the masses who are wearied of living under harsh socio-economic conditions particularly resulting from corrupt practices. President Muhammadu Buhari reaffirmed his commitment to fight corruption in Nigeria in a Foreword note in the National Anti-Corruption Strategy (2017-2020) said:

"Since I came into office in May 2015, I made fighting corruption a major pillar of my government policy. We have implemented the Treasury Single Account (TSA) hitherto impossible in Nigeria to make it impossible for public officers to divert public funds to personal accounts. Through the effective application of TSA and the Bank Verification Number (BVN), we have been able to remove 23,000 nonexisting persons from our pay roll and by this singular act, saved billions in funds that would have been stolen. We are currently reviewing our anti-corruption laws and my government has already signed the Open Government Partnership initiatives and completed the National Action Plan for its effective implementation in Nigeria. FMJ (2017).

This administration is therefore seen by Nigerians as the restorer of order into the social system. This is not farfetched from the past experience the nation in the early 1980s under the Buhari/Idiagbon military regime which had records of fighting corruption and instituting order to the society. Another reason was the campaign promise of good governance and probation of past administrations for embezzlement and misappropriation of public funds.

The current administration of President Muhammadu Buhari has made the fight against corruption and the restoration of integrity in governance a priority. This is manifest in the President's commitment at the May 2016 London Anti-Corruption Conference 2; the setting up of the Presidential Advisory Committee on Corruption (PAC); establishment of the National Prosecution Coordination Committee (NPCC); the re-submission of two key anti-corruption bills: the Mutual Legal Assistance in Criminal Matters Bill and the Money Laundering (Prohibition and Prevention) Bill to the National Assembly for expedited consideration; the ongoing review of both the Nigeria Financial Intelligence Agency Establishment Bill, and the Proceeds of Crime Bill; the commitment to prosecute corrupt public officials; the recovery of looted public funds; and the development of various justice sector reform initiatives (CDD, 2016).

To date, there are several cases of past and present public officers and politicians under investigation, series of indictments by the various anti-corruption agencies which have been empowered and reinvigorated to take on the task. Also recovered funds in foreign countries have been returned and thousands of ghost workers have been discovered and their pay running into millions of Naira monthly have been remedied and lots more. The Anti- Corruption Bill of Muhammadu Buhari which has been in the National Assembly since February 2016 has been passed into Law on May 30, 2017 which is a major stride in the war against corruption. The Executive Bill christened "Mutual Assistance in Criminal Matters" is meant to facilitate the identification, tracing, freezing, restraining, recovery, forfeiture and confiscation of proceeds of crime [11].

\section{Statement of problem}

Corruption thrives virtually in all ramifications of human endeavors in Nigeria with the most endemic committed by public officers and highly placed people in governance over the years. The need for the media to drum hard the beat against corruption is paramount. The media have been very instrumental and at the fore of enlightening people through campaigns and programming, news and editorial contents to explain the benefits of moral astuteness as key to national development.

The Buhari led administration with a resolve to eradicate corruption has carried along the media in achieving this objective. Thus, the study seeks to find out the role of the media in the race against corruption as the administration has spent almost half its tenure.

\section{Objectives of the study}

- To determine the frequency of reports on corruption in the Nation and Daily Trust newspapers

- To determine the direction in which issues of corruption are reported in the newspapers.

- To examine the prominence given to issues of corruption in the selected dailies.

\section{Significance of the study}

The study will be of immense importance to both the Nigerian media and the masses who are of course the media consumers. The media are conventionally said to be the watchdogs of the society who not only entertain but educate, enlighten and inform on happenings near and far.

The media would hardly be informing and enlightening the public: if they do not cover, report and broadcast daily happenings; if they do not examine and investigate irregularities and report findings and if they do not create avenues for the public to contribute their own opinion as part of corporate citizenship, thus helping everybody to feel part and parcel of societal development.

To these end, the findings of this work will reveal whether the media have been living up to expectations in the area of the fight against corruption by the present government.

\section{Scope of the study}

This study will examine The Nation and Daily Trust newspapers reports and coverage of issues of corruption in Nigeria with a particular focus on the frequency, tune and prominence given to such issues. These two dailies were selected considering their national outlook, the regions in which they are published and availability for the sake of ease for the researcher.

The duration of the study will be the daily publications of the Nation and Daily Trust from Mondays to Fridays within the period of six months (July to December, 2016) where the Buhari Administration has stepped up its campaigns against corruption. Particularly, the issue of the 2016 Budget Padding became topical as the National Assembly was accused of adding or including funds into the document submitted to them by the Executive arm of government. These funds were not justified as far as the executives are concerned. While the former Chairman the House Committee on Appropriation Honourable Abdulmuminu Jibrin blew the whistle thus, the issue became topical and a subject of discourse in the public sphere as well as media issue. This posed great question to the resolve of the Buhari led administration to fight corruption. Both newspapers carried straight news, features, editorials, cartoons, columns etc. that reflected on the issues in this period. There were also several indictments of individuals by the Economic and Financial Crimes Commission. Example is the former Governor of Katsina state, Alhaji Ibrahim Shema for alleged embezzlement of funds and inflation of contract figures while in office. 
Another phenomenal case is that of indicting justices for corruption charges.

\section{Research questions}

- How often do The Nation and Daily Trust cover issues of corruption?

- What is the direction of reporting corruption in The Nation and Daily Trust newspapers?

- What prominence do The Nation and Daily Trust give to issues of corruption?

\section{Operational definitions}

Media: The plural form of medium. Medium means that by which something is expressed. In this study, media is the same as mass media. The mass media are the modern channels of mass communication used to disseminate information to a very heterogeneous large number of people.

Role: A part played by the media in the fight against corruption.

Corruption: It is the act of drawing away from the right path, in the context of this study, it means dishonest behaviour used to achieve an aim.

Campaign: Series of planned activities to gain special objectives. In this study, campaign refers to series of media activities geared towards achieving a particular goal or publicity. It can be in the form of programmes whether in broadcast or in print media.

Anti-corruption: This refers to measures designed to eradicate, prevent or discourage dishonest and fraudulent behaviour used to achieve an aim.

War against corruption: It refers to measures taken to stop the use of dishonest means or behaviour to achieve an aim. It also includes measures taken to forestall such practices seen as corrupt.

\section{Review of Related Literature}

\section{The role of the media in combating corruption}

Boadu [12] posit that communication, undoubtedly, contributes to socio-economic development. The media, with their integrative and interactive abilities, have helped in shaping the socio-economic development of communities, countries and the globe at large. Evidence abounds to show how the convergence of communication (as conveyed in mass media contents) and political leadership has affected the socioeconomic development especially when development is viewed as social and material advancement or improvement in the quality of life, self-reliance and improved living conditions.

The mass media can furnish useful information to the people at large constantly because they reach the largest section of the society directly or indirectly or through secondary readership and viewership regular and intimately [13]. Apart from the government and the people, another party that has a major role to play in tackling rape and gender base violence in Nigeria is the media. Mboho 2005 added that the media have been known worldwide to possess certain qualities that make their uses imperative if the communication is aimed at a wider and heterogeneous audience. However since the media cannot be isolated in matters of corruption, it is expected that they give prominence to the issues of corruption.

According to Shields, Goidel and Tadlock 1995 mass media contents have been found to affect voting decisions, reproductive behaviour spirituality political knowledge party politics and candidate saliency [13-15] electoral choice and voting stability and so on. Remarkable correlation has also been established by Schramm [16] and McNelly [17] between the mass media and economic development) in Western and Latin American countries. But can the same be said of media with regard to corruption? In developing countries, particularly in Nigeria, have the media in any way helped in reducing corruption?

Qualitative, independent media reporting on corruption can play an important role in pressurizing the government to act in public interest. Rose-Ackerman [5] revealed that by drawing the attention to behaviour that is generally perceived as acceptable and exposing such behaviour as corrupt, media can raise public awareness; activate anticorruption values; and generate outside pressure from the public against corruption.

Media are central to changing people's beliefs about the prevalence and legitimacy of corruption. This ability to mould perceptions, norms, and behaviour is fundamental to their importance in the fight against corruption. Rajak [18] maintains that the media may not be traditional tools in the fight against corruption. However, they are crucial in achieving the cultural change that must accompany any legislative change to make laws and institutional changes sustainable. Media can amplify the effect of anti-corruption legislation by

a) Reaching and mobilizing a broader audience;

b) Motivating political leaders to act;

c) Facilitating a cultural change that will improve the sustainability of change.

The impact of media reporting on corruption can be tangible and intangible [7]. However, the role of the media in combating corruption becomes tangible when media coverage on corruption issues has a positive effect on the audience thereby resulting in an outcry to checkmate such ill practices in a given society. Media role in combating corruption can be intangible when media coverage lacks transparency and objectivity that will bring about the required positive change and development in the society.

Stapenhurst [7,19-23] explained that how well media can perform its watchdog function against corruption, fundamentally, depends on a number of factors defined by the political, economic and legal environment in which the media operate: however media freedom, freedom of expression, access to information, ownership, competition, credibility and outreach are some have been identified as the major factors that determine the quality and effectiveness of media performance on corruption.

According to Eigen 1999, Media can play an important public accountability role by monitoring and investigating the actions of those who are granted public trust and who may be tempted to abuse their office for private gain hence the role of the media in combating corruption cannot be overemphasized.

The newspaper as a medium of mass communication is very powerful in influencing people through its agenda setting abilities; the newspaper set topics for public discussion. People mostly tend to live by what they see, listen or read from the media. The newspaper is mostly restricted to only the literate and financially strong members of the society who can buy and read. The newspaper has an edge over radio and television due to its unique features. The newspaper provides indepth and interpretative information in the form of features, in-depth 
news, investigative reports, cartoons, special columns news analysis etc. Also, newspapers provide permanence and convenience to its readers; it can be stored for a long period and can be read at will unlike radio and television which are transient in nature. Thus, the Nigerian press have a role to play in forming public dialogue that would help in social change.

According to Oso 2003, national development is a multidimensional process, the end product which should be a qualitative improvement in the standard of living of the people. Oso 2003 furthered that it is a process concerned with how people exploit their God-given resources to satisfy their needs, manage and induce change within a given historical period. He quoted a former Secretary- General of USCSTD definition of development in this way: "Development must transcend purely economic dimensions in order to include social considerations - food, health, living conditions and employment - and the whole dimension embracing creatively, quality of life and the rights of man."

The press is part and parcel of the lives and aspirations of the people, it ensure the participation of the readers in the process of social development. Stemming from this is the fact that the principal purpose of the media is development, development conceived not just in terms of economical indices but more in terms of justice, equity, better access to social resources and freedom of expression.

Another pertinent point is the fact that for the Nigerian press to remain and function as one it cannot be run as the agitators of the elites. It must be radically different in operation, organisation, philosophy and content. Relevance must be the core values which must inform its operation and professional judgement in terms of news selection and treatment. As the mirror of and window to the society, the content of the newspapers must reflect the interests and aspirations of the people. Stories must be inclusive; no group must be marginalised; no view or perceptive distorted; sources and sourcing for news must be diverse and sensitive to the social composition of the society.

McQuails 1987 defines communication as the sending of a message about something to someone who is a receiver. Fiske [24] says that communication is social interaction through message, a human activity that is easily recognizable. Fiske's definition strikes a linkage with Servaes's description of communication for development as a social process.

It is worthy of mention that communication is an important social tool, without it, one could not have influenced the ideas, feelings or actions of others. Through written, verbal and non-verbal signs and symbols, man communicates his feelings and ideas to his fellows. Those who have cultivated the ability to communicate are better than those who cannot express themselves properly. For those who know how to communicate, learn to interact; can achieve leadership in the groups they involved. It is also true that communication links the individual with himself, his environment and other men. The man of our time lives in a diversified media world, the profusion with which they are distributed and the assault of advertising. There are few communities that may still be totally isolated and outside this communication circle. Through the media, man has become accustomed to receiving messages. Communication serves as an instrument of social interaction. It helps us to understand ourselves, to keep in touch with other people, to understand situations. It is a means by which power is acquired, exercised and sustained. It is the medium through which relationships are established, extended and maintained. The Mass media has helped in creating social awareness and also provided people with an easy way of life. The print media played an important part in the historical events such as: one of the social institutes that complement other institutions in other to achieved development in the society. The mass media should work hand in hand with other institutions to have total transformation, national development, total performance and growth in all aspect of human endeavour; economy, advancement in agriculture production, education, standard health care delivery at both primary and secondary levels, promotion and sustenance of culture and political stability.

Furthermore, beyond information and transmission role of the media, the newspaper provides to a large extent background details relevant to the news, explanations of related events, analysis of their importance and implication. The newspapers possess the capacity to take care of the responsibility than most other media. This is also supported by the views of scholars like Dennis and Defleur 1994.

According to Akinfeleye [25], national development is a rapid transformation of political, social and economic sectors and necessary machineries to mobilise human and financial resources towards achieving horizontal and vertical integration, through availability of flexible system that allow for change and transformations.

McNair [26] outlined five functions of the mass media in an ideal democratic society to include informing the citizens, educating the citizens, a platform for public political discourse, to give publicity to governmental and political institutions and a channel for the advocacy of political viewpoints. It is therefore the job of the Nigerian press to inform and keep the public abreast of the happenings in the political sector of any society or institution.

Schramm posits that media plays only a supportive role and not a leading role in achieving national development. Information that flows to the masses through the media helps in improving their standard of living. Media should identify issues and problem that have direct link to development (health, education, security, food, shelter, freedom of expression, and equity). The mass media should build a climate of development through coverage of such issues and initiate creation of policies through discussion. Media should mobilize people to participate in implementation of policies that will lead to development. They monitor the implementation of development policies, record and project the success and failure of such implemented policies.

Okosun [27] observes that anyone not very conversant with Nigerian political affairs, who stumble onto a Nigerian news portal, could very easily be misled into thinking that Nigeria is at war, largely due to the vituperations of politicians published in the media Geer [28] posit that to the outside observer presidential campaigns often appear chaotic largely due to press coverage of such issues McNair [26] outlined five functions of the mass media in an ideal democratic society to include informing the citizens, educating the citizens, a platform for public political discourse, to give publicity to governmental and political institutions and a channel for the advocacy of political viewpoints. It is therefore the job of the Nigerian press to inform and keep the public abreast of the happenings in the political sector of any society or institution.

\section{The frequency of mass media coverage of war against corruption}

The enhanced awareness of the role of the media in curbing corruption has been demonstrated going by the current rise in the use of information technology in various social processes worldwide. the role of the media in propagating and advocating for developmental ideologies cannot be overstated thus development is consistent with 
the established position that the media helps to stimulate attitude change and, by so doing, ensure socio-economic transformation $[16,29,30]$. In light of the above, Gauntlett 1998 notes that, it is perhaps not far-fetched to expect the media to assist Nigeria to reposition itself as a democratic polity with a strong commitment to transparency and accountability. This is expressly because on 29 May 1999, the new regime of President Olusegun Obasanjo publicised its resolve to fight corruption and enthrone a new, improved manner of conducting public business in Nigeria. In the new dispensation, corruption has to be exposed, punished and eliminated therefore the media have stakes in curbing corruption via coverage and reportage.

McQuail and Windahl 1986 postulate that frequency is a key determinant of agenda setting function of the media. Ngoa [31] posit that audiences not only learn about public issues and other matters through the media, they also learn the importance to attach to issues or topics from the emphasis the mass media place on them. Agenda setting describes the powerful influence of the media on the audience. The decadence in the Nigerian media has been the concern of international organizations as well.

The World Bank Regional Communication Adviser, Akin Fatoyinbo, emphasised the need for Nigerian journalists to always check information for accuracy before dissemination (Sunday Vanguard, 22 July 2001, p. 17). Akpan 2001 has observed that journalism practice in these parts has been reduced by a good number of its practitioners to something akin to black-mail journalism. Indeed, investigative journalism to a large extent has been thrown out of the window or dethroned to the detriment of a healthy, responsible and reliable media practice. Even though the point has been made against the unprofessional media practices by the press, the impression should not be moulded that the situation elsewhere is much better.

The Nigeria media generally tends to treat allegations of corruption with benign neglect. In its issue of 18 July 2001, p. 48, This Day, for example, published the text of an open letter to President Olusegun Obasanjo in which serious allegations were made against his administration thus: Hence Transparency International still ranks Nigeria to be one of the most corrupt nations in the world Akpan 2001.

In Nigeria, Agbaje 1992 and Uche 1989 have established that both the public and private proprietors stay focused to their narrow, personal concerns which tamper with the ideals and professional ethics of journalism hence media coverage in Nigeria in terms of curbing corruption is epileptic. This is obvious in the tune of reports on corruption where it happens to be reported.

However, Oyovbaire 2001 added that the media has been accepted quite reluctantly by media scholarship and practice that the media is a powerful instrument and agency for setting and executing its own agenda for its own target audience. This agenda-setting role includes deliberate suppression of otherwise critical issues of public interest, gross diversion of public attention, selective target of issues and/or personalities for public and national discourses, and deliberate foisting upon the public of particular images as well as contents about public policy. The method for doing this is at times subtle, and at other times brazen, the result is that the media has acquired a very powerful and significant status of its own to the detriment of transparency and accountability in government in Nigeria.

As pointed out earlier, the media industry is a cluster of several stakeholders which include media scholars, professional communicators, journalists, media owners, newsmakers and media users. Each of these stakeholders has its own interests and is passionate about them and will engage any instrumentality to protect them. The diversity which characterizes these interests has made it totally impossible for the media to focus on its fourth estate responsibility which is holding government accountable to its citizens as enshrined in the constitution. The major challenge facing the media industry is the inability or probably refusal of mass media scholars to articulate these interests involved and put each of them in the proper perspective. Scholars, by virtue of their epistemological fountain, are naturally endowed to ensure that this is done. Unfortunately, their challenge of not being able to properly operationalize and articulate these interests, has helped to undermine the inability of the media to hold government officials accountable.

\section{The direction of reporting corruption}

The notion of the press being watchdogs to the society is more than 200 years old. Yet the idea of vigilant media monitoring government and exposing its excesses has gained new grip in many parts of the world. Globalization, the fall of authoritarian and socialist regimes, and the deregulation of the media worldwide have fuelled a renewed interest and surge in efforts by various groups to support "watchdogging" by the media.

Since the late 17th Century, classical liberal theorists had argued that publicity and openness provide the best protection from the excesses of power. The idea of the press as the fourth estate; an institution that exists primarily as a check on those in public office, was based on the premise that powerful states had to be prevented from overstepping their bounds. The press working independent of government, even as its freedoms were guaranteed by the state, was supposed to ensure this.

The 1980s and 1990s saw the revival of this old notion and its application especially to transiting societies emerging from the ruins of socialist and authoritarian regimes. It had resonance among citizens facing pervasive corruption, weak rule of law, and predatory or incompetent governments unable to deliver basic services. Today even in countries where democracy is a fairly new experiment or even in those, like China, where democracy and a free press have yet to take root, the notion of the press as watchdogs of power is embedded in the self-definition of journalists and in varying degrees, also in public expectations of the media. It is, moreover, a particularly seductive notion to the international donor community, which, since the 1990s, began to publicly acknowledge that corrupt and inept governments were a major impediment to development efforts.

Sam 2009 asserts that the Nigerian press have tried in so many ways to help in nurturing our democracy but sadly, they have equally contributed to the ravaging corruption pervading the land. Many times they expose corruption but always fail to see a logical conclusion i.e., they fail to follow up on stories some times and at other times, they are blindfolded by ownership and control or gratification which in itself is unethical.

Yushau 2008 in his finding from a study on press coverage of political corruption in Nigeria posit that most Nigerian newspapers have been bought over by corrupt elements. The major advantage of having a press in Nigeria should have been for freedom of speech particularly of the press. Durofela 2009 assert that journalists themselves should not be corrupt. They should tell the truth and print what the public should know. News and contents of publications should not take sides or favour political leanings while discrediting the opposition.

From the above, the language or tone coverage and reportage of issues of corruption should either express corruption as bad and not 
to glorify it by covering up and making it attractive to the public. The ills of corruption and its practice should be made glaring in the eyes of the public.

\section{Nigeria government and the war against corruption}

Nigeria as well as many developing countries remains stuck in corruption, crime, poverty, and violence despite the promulgation of several laws like in other countries as the principal mechanism for curbing corruption. As observed by Ijaduola 2008, the fact that Nigeria is a pluralistic society, offers the impression that implementing the MDGS may not be an easy task. The legal instruments used to fight corruption in Nigeria include the Criminal Code, Code of Conduct Bureau, the Recovery of Public Property Act of 1984 and the newly formed commissions (the EFCC and the ICPC). Prior to 1966, the Criminal Code was the primary source of law dealing with corruption in Nigeria. But due to the narrow nature in dealing with corruption such as only criminalizing the conduct of bribe-taking public servants leaving the private, it was replaced by Criminal Justice (Miscellaneous provision) Decree in 1966. This however failed to stem the tide of corruption.

The rules were confusing, thus leaving open the livelihood that guilty persons might escape punishment on technical grounds. The Code of Conduct was thereafter formed in the 1979 Nigeria constitution where complaints on corrupt practices are referred to Code of Conduct Bureau Tribunal. The Bureau forbids public officers from simultaneously receiving remuneration of two public offices and from engaging in private practices while in the employment of government, the code bar public servants from accepting gifts or benefits in kind for themselves or any other person on account of anything done or omitted to be done in the discharge of their duties. It prohibits public officers from maintaining or operating foreign bank accounts. Public officers are required to declare their assets and those of their families immediately after taking office, at the end of every four years in office, and at the end of their terms. Due to the non-inclusion of the private sector which are also corrupt in all these laws. In year 2000, the Independent Corrupt Practices and Other related Offences Act was promulgated which eventually gave birth to the ICPC and the EFCC charged with the responsibility of investigating, arresting and charging any offenders with corrupt practices either economic or financial crimes in Nigeria.

However, Iroja [32] observed that the lack of diligent prosecution by the EFCC has led to the loss of many high profile cases. Perpetrators of massive fraud and looting get acquitted on legal technicalities. This clearly points out that the convictions made by the United Kingdom Courts are an indictment on the Commission for its inability to successfully prosecute the same charges and offences. Successful prosecution of major cases in consonance to the standards of the United Kingdom Courts will have made restitution easier to the Nigerian people whose salaries, pension, gratuities, healthcare system, education, roads, pipe borne water, electricity, general infrastructure and long term investments were stolen from them. Other reasons for the underperformance of the Commission include inefficiency of the judiciary, lack of societal cooperation, poor staff training, pleabargaining and systemic disorder as outlined by Sheriff Folarin in a forum at Covenant University, Nigeria.

The Chief Justice of Nigeria, Justice Mahmud Mohammed, recently stated that the reasons behind the high failure of the EFCC to successfully prosecute high profile corruption cases stems in part from the numerous amount of charges tied to each individual case.
In his words "Courts cannot carry out investigation and our security agencies must be encouraged to carry out investigation-led arrest and not arrest-led investigation." He explained that the commission must call more than one witness to testify on each count in the charge for prosecution to be successful.

\section{President Muhammadu Buhari and the war against corruption}

Since taking office, President Muhammadu Buhari has demonstrated an unprecedented political will to fight corruption unlike his predecessor, Goodluck Jonathan who appears to have paid little or no attention to corruption and its scandalous manifestations. Jonathan's quest and ambition for second term in office beclouded his sense of judgment and totally bamboozled his political will from fighting corruption to cementing loyalists in all regions of the country through dubious transactions [33]. Jonathan was seen to have pampered corruption and had soft pedalled for his cronies by stating that stealing is not corruption.

According to Ekpo et al. [33], President Buhari has continually alerted Nigerians that if Nigeria does not kill corruption, corruption will kill Nigeria. Despite these positions however, the anti-corruption fight tends to emphasize more on fighting the manifestations of corruption and neglecting the root and the vector of the germ. Just like his predecessors, the modus operandi of his war against corruption is to arrest suspected looters with any of its intelligence agencies, employ the antics of its anti-graft agencies for general probing and investigation, then charge the suspect to court for prosecution. Buhari has slightly deviated from his predecessors by placing utmost priorities on recovering looted public funds and even generating more funds through compromised court judgment and bail charges; while the much anticipated fight against corruption is negated. For instance, several top government officials of the Jonathan administration were indicted in the $\$ 2.1$ billion arms purchase scandal have been arrested by the Economic and Financial Crimes Commission (EFCC). Some adamant ones like Colonel Dasuki (former National Security Adviser) and Olisa Metuh (Publicity Secretary of the People' Democratic Party), were tried and remanded on several count charges [33]. The presidency has advised those who looted public funds to quietly return them for soft landing. It has also been made clear that a quota of the proposed 2016 budget will be funded with recovered looted funds.

The Economic and Financial Crime Commission (EFCC), Independent Corruption and Other Practices Commission (ICPC) and Code of Conduct Bureau (CCB) and other anti-corruption agencies are seen vigorously prosecuting the war against corruption (CDD, 2016). It has been noticeable in our society that the fight against corruption is a major project before the present administration. Media reports and people in Nigeria describe the personality of Buhari as one who detests corrupt practice in its various ramifications. Constantly, the body language of the president has been to eschew and frown at corruption. This has been indicated in the manner in which public officers, Ministries, Departments, Agencies and Parastatal readjusted themselves and their operations immediately after his taking over office. Log books were opened in most government offices to monitor prompt entry to offices and the time of closing each working day.

Ekpo et al. [33] opined that Buhari's use of the EFCC in combatting corruption is misguided and would yield no better result as the nontransparent structure has only enmeshed more woes on his ill-defined anti-corruption strategy. The administration has continued to cover its cronies such as Rotimi Ameachi and Babatunde Raji Fashola former 
Governors of Rivers and Lagos State respectively for several petitions on corrupt acts.

\section{Theoretical framework}

Agenda setting provide theoretical backing to this study. The notion of Agenda setting started with Walter Lippmann's observation that the mass media mediate between the world outside and the picture in our heads Lipmann 1922. Cohen 1963 asserted that the press is significantly more than a purveyor of information and opinion. Cohen restated that the press may not be successful much of the time in telling people what to think, but it is stunningly successful in telling readers what to think about Cohen 1963.

Lippmann and Cohen's submissions were results of their personal observations which lacked empirical footing. However, McCombs and Shaw established an empirical link between media agenda and public agenda in their studies McCombs and Shaw 1964.

McCombs and Shaw 1964 opined that the mass media have the ability to transfer the salience of items on their news agenda for the public agenda. People judge important what the media judges as important. The media does that by deciding what to place emphasis on in their news pages thereby the media set the agenda of the day.

McCombs and Shaw furthered their argument that the mass media set agenda for public discussion using the outcome of their study of an American presidential election to a theory which has generated critical and sustained attention from researchers. Central to the Agenda setting theory is the idea that the media influences the level or importance people attach to what they see, read or hear from the mass media. This suggests that the mass media shapes how the audience construct social reality. For example, through selecting certain events and ignoring others and by determining how the selected events are reported, this influences the perception of social reality by the public.

Agenda setting theory is relevant to this study because if the media set the agenda of public discussion, it is assumed that sustained media coverage of corruption will directly influence the level of importance the Nigerian public attaches to the issue. Therefore, the more attention the mass media devote to reporting issues of corruption, the more likely the public will consider these issues to be important. For instance, White [34] argued that the world looks different to different people, depending not only on their personal interest, but also on the map that is drawn for them by the writers, editors, and publishers they read.

Furthermore, the media not only influence what we think about but influences the way we think about them. This is achieved through framing. Framing is a graduated form of agenda setting theory developed by McCombs and Ghanem [35]. McCombs argues that agenda-setting operates at two levels: the object level and the attribute level. Conventional agenda-setting focuses at the object level and assesses how media coverage influences the priority assigned to issues. The media can also tell us how to think about some issues. Media do this by influencing second order i.e., attributes agenda. They tell us which attributes are important and which ones are not. This is done by the media through selection, emphasis, exclusion and elaboration of issues. These help to determine the salience of particular attributes of a story or issue. Media not only tell us what to think about, they may also tell us how and in what way to think about it, and possibly what to do about it. McCombs believes that the integration of agenda setting theory with framing theory will help clarify some of the concepts in the framing theory. He advocates clarification of a more general theoretical structure describing the frames and attributes that are important to the communication process [35].

In reporting issues of corruption, the mass media are able to direct the minds of their audiences through emphasis or repeated reports and coverage, placement and prominence given to issues thereby such issues occupy the minds of the audience and becomes important part of public discourse. A good example is the sustained coverage and reporting of the budget padding issue by the Daily trust and The Nation for example was the topic of discussion over a long period of time among Nigerians hence became a successful media and public agenda as well.

From an opposing stance, Oheneaboagye [36] identifies that the agenda setting theory fails to address certain important issues. The theory assumes that if people are exposed to the same media contents, they will place importance on the same issues. Oheneaboagye [36] argues that this assumption is not true. According to him people have different frames of references therefore what one may consider important after filtering the issues through his frame of reference is different from the other person's. People are therefore not always likely to place importance on the same issues even if they are all exposed to the same media content.

Oheneaboagye [36] and Ceaser 2010 further argue that agenda setting theory fails to consider the personal interests of individuals. Any issue considered salient by the mass media and put in the public domain will not necessarily be considered salient by the public. The audience consciously chose media products that they get gratification from or addresses their individual needs. It is such issues they might consider to be salient. The theory assumes that once the media considers any issue to be salient and give it dominance, the public automatically regards the issue as salient. The public only considers such issues salient if they personally have interest in them. In such situation, one cannot claim that the issues are considered salient by the audience simply because the media regard them as salient, but rather because they serve the interest of the public. The Agenda Setting theory uses a very scientific approach, not humanistic, and therefore in practical terms it is not able to stand the test of scrutiny since human beings are known to be very unpredictable. Nonetheless, it is a very useful theory in the effect tradition of the mass media [36].

The agenda setting theory fit into this study to explain how the mass media identify the issues of corruption and the fight against corruption such as trials, whistle blowing, raids and activities of the agencies as salient and stress them for public consumption. In this respect, the mass media become agenda setters and the issues of war against corruption become the agenda.

The agenda setting theory and the complementing theories of framing and priming relatively fit into this study. Framing and priming are advance form of agenda setting as stated earlier. Priming emphasizes the ability of the mass media to give prominence to a particular issue in public domain. Corruption issues in this context become the prime issues. They are given more space, prominence in terms of placement on the media. The frequency of such issues become higher hence people's attention is likely to be drawn to such issues as they keep recurring and placed on pages regarded as prominent.

However, Akagbosu and Omoruyi [37] and Galadima and Enighe [38] observed that the mass media in Nigeria often give more coverage to political issues than other pressing issues of national interest. In a related study on the evaluation of press coverage of children's and women's right, conducted by Nwodu and Ezeoke [39] empirical 
findings reveal that that $87.4 \%$ of the stories on women's and children's rights were found in the inside pages of the newspapers leaving insignificant $9.2 \%$ and $3.4 \%$ respectively for the front and back pages. This simply implies that while not enough coverage was given to the issues, the little coverage on the issues found were not accorded the prominence they deserve. Positioning the bulk of the stories on women's and children's rights in the inside pages while leaving only $12.6 \%$ for both the front and back pages that are considered strategic positions in the press shows that the press did not consider crucial issues of women's and children's rights important enough to merit the strategic positions. Ngoa [31] posit that audiences not only learn about public issues and other matters through the media, they also learn the importance to attach to issues or topics from the emphasis the mass media place on them. Agenda setting describes the powerful influence of the media on the audience.

The findings of the above study validates the agenda setting theory in which White [31] and Ndolo [40] agree that much of what the public know about issues around them depend so much on the map that is drawn for them by the writers, editors, and publishers they read.

On the same theoretical framework of this study is framing. Framing goes beyond the presentation of salient issues but includes how the issues are presented. Framing substantially affects how the public perceives news and events [41,42]. According to Entman [41] framing is the selection of some aspects of a perceived reality and make them more salient in a communication text, in such a way as to promote a particular problem definition, causal interpretation, moral evaluation, and treatment recommendation for the item described. Frames provide a mode of organization for journalists who report news events and the public who consume the news. News reporting styles and conventions such as space and time allocation, headline size, placement or positioning of news stories, use of quotations are strategies used by journalists and editors to increase or reduce the salience of a news report. The fight against corruption under the present Buhari administration is portrayed with utmost seriousness.

Therefore, the prominence news media attach to an event could be determined by examining what is included, excluded or suppressed in the story. Peng [42] defines framing as a process of inclusion and exclusion. Similarly, Entman [41] posit that frames call attention to some aspects of reality while obscuring other elements which might lead audiences to have different reactions. From these submissions therefore, what the media in include, exclude or suppress in the process of framing issues of corruption will determine to a large extent how the public will perceive the issues. This implies that when the media frames corrupt people as unpatriotic and selfish, the public tend to regard them in same manner. Framing is concerned primarily with the manner of presentation of such issues. Are the issues presented in a glorified manner or in a detestable way? Large and sensational banner headlines were used for instance in reporting the Dasuki arms scandal in 2016 and repeatedly as the case develops, several related stories were tied to it thereby making it a public attraction for over a long period of time..

Findings of Nwodu and Ezeoke [39] also reinforced the concept of framing which gives attention to some aspects of reality while obscuring other elements which might lead audiences to have different reactions as [41] claimed. The media have power to structure and determine what the audience consider important by the extent of prominence the media gives to issues and how these issues are packaged and presented. It may be right to assume that manifest poor prominence given to women's and children's issues in the press, the audiences may have poor knowledge and perceptions of women's and children's rights' issues. From the foregoing, when prominence is given to issues of corruption by the media, audience will have a good knowledge and perception of issues of corruption which will invariably influence their mind in thinking about the agenda set by the media.

It has been observed that most public discussions relating to corruption are those that the media presented on the pages of their newspapers. This has reiterated the dispensable role of the media supporting the government in the fight against corruption. The press have also through their agenda setting role, awaken the spirit of Nigerians to be vigilant and report corrupt activities. The press have been able to establish and play significant roles in mobilising the population to support the government in its war against corruption. These reasons prompted the study to hypothesize that there is a relationship between media coverage of the war against corruption and the decrease in rate of corruption in the country.

\section{Methodology}

Descriptive approach was adopted for this research in order to investigate media coverage of the Buhari's war against corruption. Because this study is grounded on the core objective of describing media's role in the current war against corruption, Content Analysis was adopted as the research method.

From reviews of related literature, Content Analysis is explained by scholars as a method for studies. Kerlinger [43] defined content analysis as a method of studying and analysing communication in a systematic, objective and quantitative manner for the purpose of measuring variables. Berger [44] says content analysis is a research method that is used to assess the manifest content of a medium such as books, newspapers, magazines, films, documentaries and television programme. Wimmer and Dominick [45] describe Content Analysis as a research technique for the systematic classification and description of communication content according to certain and usually predetermined categories. Content Analysis is defined by Babbie and Benaquisto [46] as the study of recorded human communication such as books, websites, painting and laws. It is a research method in the social sciences for studying the content of communication.

Content analysis therefore is capable of generating valid and reliable qualitative and quantitative observations because of its unobtrusive nature. It eliminates many confusing antecedent conditions often encountered in media research when other research techniques are used. Most scientific definitions of content analysis have emphasized attention to manifest content [43]. The requirement is that the content analyst be concerned primarily with manifest content to ensure intersubjectivity does not mean that latent contents are excluded from considerations provided that the content analyst establishes explicitly formulated rules and procedures [47].

Specifically, the researcher must also decide whether to analyze only the manifest content or the latent content as well. There has been some debate as to whether hidden meanings found in documents can be analyzed, because their analysis usually involves interpretation. Researchers are guided by the aim and research question of the study in choosing the contents they analyzed. The rules and procedure of analysis remains the main guide throughout the period of analysis.

Therefore the primary concern of the researcher in this study is manifest content; this does not exclude latent content from consideration provided that the researcher establishes clearly formulated rules and procedures [47]. 
The universe of this study is all newspapers in Nigeria (both local and national dailies). The Nigerian Press Council (NPC) in the year (2015) holds that there are 51 registered Newspapers in Nigeria both local and national dailies. However it is practically not possible for the researcher to study all the registered newspapers in Nigeria but two newspapers were purposively selected. They are The Nation and Daily Trust newspapers. These are newspapers were selected by the researcher based on the reason that they have a national outlook, the regions they are published, availability, for the ease and convenience of the researcher.

Sample size is the agreed number of subjects to be involved in the study. It is mostly determined mathematically. The publications to be analysed by this study comprises of all daily publications of The Nation newspaper and Daily Trust newspaper from July, August, September, October, November and December 2016. However, only editions for the week days were selected weekend editions were exempted because they mostly carry entertainment stories and special issues such as reviews of the activities of the week, features, entertainment as well as dedicating most of its pages to specialised areas such as religion, fashion, relationship, diplomacy among others.

The population for this study is all together 240 editions i.e., 120 editions each from The Nation and Daily Trust newspapers which is summed up to a total of 240 editions. The required sample size for the study is $20 \%$ of the population.

Nwana [48] postulates that if a population is in many hundreds, a sample size of $20 \%$ is needed, but if a population is a few thousands, one needs a sample size of $10 \%$ and if a population is of several thousands, one needs a sample of $5 \%$ or less. Going by the population (many hundreds, the researcher used 20\%).

Based on the above, the sample size for the population of 240 will be 48 newspapers going by the formula below.

$$
n=\frac{N}{100} \times 20
$$

Where $\mathrm{n}=$ sample size, $\mathrm{N}=$ population.

Sampling technique is the procedure that a researcher employ in order to select a workable number of subjects out of the population. Given that the required sample size is 48 publications, the researcher selects two national dailies (The Nation and Daily Trust newspapers) out of the 51 national newspapers we have in the country using the purposive sampling technique. The selection of these newspapers was done based on their national outlook and circulation nationwide. The convenience of the researcher in accessing these publications was also a factor considered in making the purposive selection. The Nation newspaper is a frontier in the fight for good governance, rule of law and accountability in both private and public sector going by their core values. In light of the above, reporting corruption therefore falls within the areas of their interest. Daily Trust newspaper is also one of the reputable newspapers we have in the country having won numerous awards for professionalism and objective coverage of events are committed to world peace and sustainable development. This also gives them the strong backing to report issues of corruption which is a major factor that impedes development.

The months under study are July, August, September, October, November and December 2016. All the editions of the week were included in the sample except the weekend editions. This is because weekend editions do not focus much on straight news. The weekend editions focus more on special issues such as reviews of the activities of the week, features, entertainment as well as dedicating most of its pages to specialised areas such as religion, fashion, relationship, diplomacy among others. This summed the total of 120 editions for each of the two selected newspapers. Therefore, the population of the study is 120 editions multiplied by two i.e. the two selected newspapers under study which gives a total of 240 editions $(120 \times 2=240)$.

The period of six months was selected based on the fact that it was a period that recorded a lot of exposition, indictments and arrests for corruption related issues and scandals. The Buhari administration swung into action in the fight against corruption through its agencies. During the period under study, judicial officers were indicted, the Dasuki arms deal, the case of Alhaji Ibrahim Shema the former Governor of Katsina state being investigated for misappropriation of public funds and the 2016 Budget padding scandal that drew much attention of the citizens of the nation both home and abroad thereby attracting media attention.

The two selected Nigerian newspapers; The Nation and Daily Trust were purposively selected to form and conceptualise the population, while the 48 editions to be analysed will be selected using the systematic sampling technique. Asika [49] notes that systematic sampling involves the selection of the subject or item from serially listed population subjects or unit. In the course of using systematic sampling all the population has equal chances of being selected as a starting point or the initial subject.

The researcher performed a 1-in-5 systematic sample. The population of the study is 240 editions out of which 48 editions were drawn as sample. Where $\mathrm{N}=$ population, $\mathrm{n}=$ sample size $=\mathrm{N} / \mathrm{n}$ therefore $240 / 48=5$

A sample is picked from any starting point determined by the researcher from the population 1 to 240 . Using the 1 -in- 5 system, the researcher therefore samples every $5^{\text {th }}$ edition from the population to arrive at 48 editions (Table 1 ).

As shown in the table above, 48 editions of newspapers were sampled, 24 from each of the selected newspapers.

The research instrument used for this study is coding sheet. This is developed for effective content that will show the frequency of reports, prominence, direction of reporting to obtain reliable and valid information, and to ensure prompt analysis of the data that will be collected.

Babbie [50] define coding as the process of transforming raw data into a standardized form. The coding process has to do with recording the observations made during the course of the study in a form that can be analysed and understood.

\section{Content categories}

Categories are divisions into which the units of analysis to be content analysed.

The content categories for this study are:

- Arrest: The reports that give account of the reaction of the public and entirety of the society about the fight against corruption.

\begin{tabular}{|c|c|}
\hline Newspapers & No. of Editions Sampled \\
\hline The Nation & $24(50 \%)$ \\
\hline Daily Trust & $24(50 \%)$ \\
\hline Total & $48(100 \%)$ \\
\hline
\end{tabular}

Table 1: Newspapers Sampled 
- Indictments/Prosecution: legal actions and proceedings against an accused public officer on charges of looting, misappropriation public funds and other corruption related issues.

- Recovery: Reports that give account on what the government, anti -corruption agencies and other individuals are making to recover looted funds.

For this study, the units of analyses are news story, features, letters to the editor, columns and editorial in the two selected Nigerian newspapers.

\section{Placement}

- Front page

- Inside page

- Back page

Placement here clearly indicates the level of importance given to the reports, the front and back pages have more prominence compared to the inside page. A political, rescue efforts report on the front page has the overall prominence compared to both the inside and the back page; given the levels of prominence, the front pages of newspapers are considered as the most important newspaper placement, the inside pages which begin from page two are considered as least important and while the back pages are considered as the important.

\section{Direction}

- Negative

- Positive

- Neutral

In this regard, the researcher will look out for the positive, negative or neutral plots on corruption from the selected dailies.

- Positive: This indicates stories or reports in the selected Nigerian newspapers which present or support the fight on corruption issues raised in the report.

- Negative: This represents reports in the selected Nigerian newspapers that do not support the anti-corruption campaigns raised in the reports.

- Neutral: this represents reports that were neither favourable nor unfavourable to the fight against corruption.

Data will be presented and analysed using simple tables and percentages. Data presented will be described according to the objectives and research questions of the study.

\section{Data Presentation and Analysis}

In this study, data analysis was based on the manifest information obtained from the selected newspapers to reflect the different categories of variables as stated in chapter three. To ensure clear presentation of statements, the content categories have been presented in tables and in descriptive statements from each of the two selected national dailies (The Nation and Daily Trust Newspapers).

It is necessary at this point to state that this study was conducted not without some challenges. The researcher encountered challenges which necessitated careful adjustments to be made in order to contain them while bearing in mind the objectives of the study and ethical principles of research. Challenges encountered include the lack of access to a few copies of The Nation newspaper editions that fall within the sample drawn hence subsequent day's edition (next day's edition) was used for analysis. This was however a result of constraints in the circulation of the newspaper to Maiduguri which has been at the heart of attacks by insurgents causing delays or the lack of supply in some circumstances.

\section{Inter-coder reliability}

The researcher selected a coder as a research assistant to code the same content independently using the same instrument while conducting the study. This is to ensure reliability of the data collected for analysis. Coding sheets prepared to generate data for this study were used. Wimmer and Dominick [45] posit that inter-coder reliability refers to the levels of agreement among independent coders who code the same content using the same instrument. Reliability is determined using the formula:

$$
\text { Reliability } \frac{2 m}{N 1+N 2}
$$

where $\mathrm{m}$ is number of coding decisions the coders agree

$\mathrm{N} 1+\mathrm{N} 2$ is total number of coding decisions of the first and second coders respectively.

$$
\text { Thus } \frac{2 \times 322}{409+409}=0.78
$$

From the above, each of the coders identified and categorized 409 items but agreed on 322 items. The Reliability Coefficient therefore is 0.78. This indicates that there is internal consistency of the instrument.

\section{Frequency of the reports by the selected newspapers}

In this section, data was collected and addressed based on the objective 1 and research question 1 of the study in table below.

Table 2 reveals that the selected dailies gave much attention to reporting corruption within the period under study. A total of $409(100 \%)$ items were reported by the selected dailies. Individually, The Nation reported 233 (57\%) items while Daily Trust had 176 (43\%) items.

The result in Table 3 reveals that, of the three categories on corruption issues, indictments/prosecution had the highest frequency of reports with $305(74 \%)$ items followed by arrests with $60(15 \%)$ items. Recovery however received the least number of coverage with $44(11 \%)$ items. This shows that issues on indictments/prosecution and arrests received more coverage than recovery.

On an individual basis, The Nation covered 163 (39.9\%) items on indictments/prosecution, 27 (6.6\%) items on recovery with $43(10.5 \%)$ items on arrests while Daily Trust had 142 (34.7\%) items on indictments, $17(0.7 \%)$ items on recovery and $17(0.7 \%)$ items on arrests.

\begin{tabular}{|c|c|}
\hline Newspapers & Total (\%) \\
\hline The Nation & $233(57 \%)$ \\
\hline Daily Trust & $176(43 \%)$ \\
\hline Total (\%) & $409(100 \%)$ \\
\hline
\end{tabular}

Table 2: Frequency of reports by the selected dailies.

\begin{tabular}{|c|c|c|c|}
\hline Content Categories & The Nation & Daily Trust & Total (\%) \\
\hline Indictments/ Prosecution & $163(39.9 \%)$ & $142(34.7 \%)$ & $305(74 \%)$ \\
\hline Recovery & $27(6.6 \%)$ & $17(0.7 \%)$ & $44(11 \%)$ \\
\hline Arrests & $43(10.5 \%)$ & $17(0.7 \%)$ & $60(15 \%)$ \\
\hline Total (\%) & $233(57 \%)$ & $176(43 \%)$ & $409(100 \%)$ \\
\hline
\end{tabular}

Table 3: Frequency of reports for each content category by the selected dailies. 
Total reports covered by each daily as shown by the table are: The Nation had 233 (57\%) items reported while Daily Trust had 176 (43\%) items reported (Table 4).

Findings from the table above shows that out of the 48 editions sampled from both The Nation and Daily Trust, 409 items were recorded. Majority of items came from News with 291 (71\%) items. The table reveals that Letters to Editor followed with 66 (16\%) items, Features with 39 (10\%) items while the Editorials constitute $13(3 \%)$ items having the least number of occurrences.

Individually, The Nation reported 169 (41.3\%) items as news, 26 (6.4\%) items as features $9(2.2 \%)$ items as editorials and $29(7.1 \%)$ items as letters to editor. Daily Trust reported $122(29.8 \%)$ items as news, 13 (3.1\%) items as features, 4 (1\%) items as editorials and 37 (9\%) as letters to the editor.

\section{Direction of reports covered by the selected newspapers}

Under this section, the data collected reflects objective 2 and answers research question 2 of the study in table below.

Table 5 answers objective 2 and research question 2 on how Nigerian newspapers report issues of the fight against corruption. The study reveals that issues of corruption reported by selected dailies were positive. There are $332(81.2 \%)$ items reported in a positive direction followed by negative stories with $64(15.6 \%)$ items and 13 (3.2\%) items reported in neutral direction in the study.

Individually, the respective dailies reported thus: The Nation had $186(45.5 \%)$ items in a positive direction, while $41(10 \%)$ items were reported in a negative direction and $6(1.5 \%)$ items neutrally. Daily Trust had $150(36.7 \%)$ items reported in a positive direction, there are $23(5.6 \%)$ items reported negatively and $7(1.7 \%)$ items were reported in a neutral direction.

\section{Prominence Given to Issues of Corruption}

This unit addresses objective 3 and research question 3 on the prominence given to the corruption issues (Table 6). Table 6 shows that out of 409 stories only $80(20 \%)$ items appeared on the front pages, while $12(3 \%)$ items appeared on the back pages, the inside pages contained more stories on corruption issues than the front and back pages. The inside pages had buried within 317 (77\%) items. The table reveals that the inside pages have the highest frequency of reports on corruption issues, the front pages ranked the second while back pages covered the least reports.

\section{Discussion of Findings}

\section{Frequency of coverage on issues of corruption}

Providing answers to the first research question how Daily Trust covers issues of corruption. The study found that issues on corruption were reported frequently, considering the volume of stories carried in the selected newspapers during the period under study. The Nation has (57\%) while Daily Trust (43\%). Looking at the frequency by the units of analysis, majority of the coverage by the selected newspapers were on news stories with (71\%), features (10\%), Editorial (3\%) and letters to Editor (16\%) The result also reveals that of the three categories on corruption issues, indictments/prosecution received highest reporting with $305(74 \%)$ items followed by arrests with (15\%). Recovery however received the least number of coverage with (11\%). This shows that issues on indictments/prosecution and arrests received more coverage than recovery hence The Nation and Daily Trust give more attention and prominence to issues of corruption. Corruption is one of the public affairs that newspapers report with intense attention. The study found that the coverage is done regardless of the type of issue. The bases of the finding that indictments/ prosecution and arrests have higher coverage buttress the fact that newspapers are usually interested in stories that capture readers' attention. Issues of prosecution have remained one of the passionate public issues that people follow so much on the mass media.

This study however differs from the positions of Akagbosu and Omoruyi [37] and Galadima and Enighe [38] which posit that the mass media in Nigeria often give more coverage to political issues than other pressing issues of national interest. In this regard, this is one of the reasons why newspapers cover issues that are related to corruption. In Nigeria, most of the issues of corruption are related to politicians (either partisan politicians or non-partisan politicians). The study found here that newspapers in Nigeria cover issues of corruption whether related to politics or otherwise.

Related to the above stated views, Agbaje 1992 and Uche 1989 have established that both the public and private proprietors stay focused

\begin{tabular}{|c|c|c|c|c|c|}
\hline \multirow[t]{2}{*}{ Newspapers } & \multicolumn{4}{|c|}{ Units of Analysis } & \multirow[t]{2}{*}{ Total (\%) } \\
\hline & News & Features & Editorial & Letters To Editor & \\
\hline The Nation & 169 (41.3\%) & $26(6.4 \%)$ & $9(2.2 \%)$ & $29(7.1 \%)$ & $233(57 \%)$ \\
\hline Daily Trust & $122(29.8 \%)$ & $13(3.1 \%)$ & $4(1 \%)$ & $37(9 \%)$ & $176(43 \%)$ \\
\hline Total (\%) & $291(71 \%)$ & $39(39 \%)$ & $13(3 \%)$ & $66(16 \%)$ & $409(100 \%)$ \\
\hline
\end{tabular}

Table 4: Frequency of coverage of corruption based on unit of analysis.

\begin{tabular}{|c|c|c|c|}
\hline Direction & The Nation & Daily Trust & Total (\%) \\
\hline Positive & $186(45.5 \%)$ & $146(35.7 \%)$ & $332(81.2 \%)$ \\
\hline Neutral & $6(1.5 \%)$ & $7(1.7 \%)$ & $13(3.2 \%)$ \\
\hline Negative & $41(10 \%)$ & $23(5.6 \%)$ & $64(15.6 \%)$ \\
\hline Total (\%) & $233(57 \%)$ & $176(43 \%)$ & $409(100 \%)$ \\
\hline
\end{tabular}

Table 5: Direction of reports.

\begin{tabular}{|c|c|c|c|}
\hline Placement & The Nation & Daily Trust & Total (\%) \\
\hline Front Page & $39(9.5 \%)$ & $41(10 \%)$ & $80(20 \%)$ \\
\hline Inside Page & $186(45.5 \%)$ & $131(32 \%)$ & $317(77 \%)$ \\
\hline Back Page & $8(2 \%)$ & $4(1 \%)$ & $12(3 \%)$ \\
\hline Total (\%) & $233(57 \%)$ & $176(43 \%)$ & $409(100 \%)$ \\
\hline
\end{tabular}

Table 6: Prominence given to issues of corruption. 
to their narrow, personal concerns which tamper with the ideals and professional ethics of journalism hence media coverage in Nigeria in terms of curbing corruption is epileptic. This study falls apart from this position. The study found that newspapers in Nigeria cover issues of corruption adequately as it has become a subject of interest to the public.

Findings of this study however agrees with that of Rose-Ackerman [5] which revealed that by drawing attention to behaviour that is generally perceived as acceptable and exposing such behaviour as regarded as corrupt, media can raise public awareness; activate anticorruption values; and generate outside pressure from the public against corruption. Hence, sustained and continuous coverage of corruption related issues will awaken the public to frown at corruption in all its manifestations.

Also, Rajak [18] maintains that the media may not be traditional tools in the fight against corruption. However, they are crucial in achieving the cultural change that must accompany any legislative change to make laws and institutional changes sustainable. This study partly concurs with this position however affirm that the media are ideal tools for the fight against corruption.

\section{Direction of reporting corruption}

In providing answer for the research question: what is the direction of reporting corruption in The Nation and Daily Trust newspapers? The study found that issues of corruption reported by selected dailies were mostly positive. There are $332(81.2 \%)$ items reported in a positive direction followed by negative stories with $64(15.6 \%)$ items while there are $13(3.2 \%)$ items reported in a neutral direction in the study. This shows that The Nation and Daily Trust reports on corruption are basically tilted towards positive direction. The finding of this study establishes how newspapers work in tune with the campaign of the government of the day. The current Nigerian government has a giant stride of fighting against corruption. This is why corruption coverage was positive. Even though, it is not always that newspapers work in line with the government campaign, but in this aspect the newspapers operate in the government direction. To support the need for eradication of corruption newspapers have been incorporated into the fight and the nature of their positive coverage has established their acceptance of the campaign.

Looking at these headlines of news stories reported by Daily Trust on Monday June 20, 2016 and Tuesday August 30, 2016 respectively for instance indicates the manner in which stories takes "Results of EFCC probe of Panama Papers ready soon - Magu" and "Budget padding: CSOs storm EFCC, demand probe" are examples of stories reported in a positive direction.

On a neutral direction for example is the feature article carried by The Nation on Friday December 30, 2016 titled "Still waiting for the 'Damning Report' on Magu” by Adebimpe Josseph. The pull out reads "There is nothing that equates an effective anti-corruption agency only with Magu at the top. But the process of selecting the leadership of that institution should not become an arena for executing an agenda that erodes the credibility of that institution as well as undermines its future effectiveness".

Towing the Negative direction for example is a feature story by Olatunji Ololade published in The Nation newspaper captioned "The stink on Buhari's 'Change' (Boko Haram, a shady budget and Buhari's expensive shit)". This was a series that ran for more than two weeks on the Friday editions from December 23 and December 30, 2016 and continued into January 2017 which was out of the scope of this study. Excerpt from the article goes thus: "this minute President Buhari is a far cry from aspirant Muhammadu Buhari and President -elect Muhammadu Buhari. The man who claimed to 'belong to everybody and belong to nobody,' is undoubtedly owned by 'somebody.' This changes the narrative about Buhari." Another line reads "This moment, Buhari's version of 'change' resonates as a corny phrase... He had failed to prosecute looters of public fund -it is shameful to see him reveal the amount retrieved from looters while shielding their identities. Does he know that Nigerians are jailed for stealing $\$ 500$... while he gives looters of public funds cum mass murderers' punishments ranging from a slap on the wrist to a pat on the back."

This finding is in tandem with the findings of Yushau 2008 study on press coverage of political corruption in Nigeria. Yushau posit that most Nigerian newspapers have been bought over by corrupt elements. The major advantage of having a press in Nigeria should have been for freedom of speech particularly of the press. Newspapers in Nigeria should report the truth and not favour any political affiliations. Durofela 2009 asserts that journalists themselves should not be corrupt. They should tell the truth and print what the public should know. News and contents of publications should not take sides or favour political leanings while discrediting the opposition. Findings from this study however reveal that reports on corruption in the selected dailies were mostly positive with 341 (83\%) items reported while 68 (17\%) items were reported on a negative direction.

Generally this study stands on the fact that the mass media particularly the print media gave prominence to corruption issues in Nigeria by reporting them in positive light. This indicates that the media plays a very pivotal role in the fight against corruption particularly in the current administration of Buhari.

\section{Prominence given to issues of corruption}

Finding answer to the level of Prominence given to issues of corruption in the selected newspapers, findings from table 6 shows that out of 409 stories only $80(20 \%)$ items appeared on the front pages, while $12(3 \%)$ items appeared on the back pages, the inside pages contained more stories on corruption issues than the front and back pages. The inside pages had buried within 317 (77\%) items. The table reveals that the inside pages have the highest frequency of reports on corruption issues, the front pages ranked the second while back pages covered the least reports. This finding indicate that The Nation and Daily Trust newspapers report on corruption mainly in the inside pages.

Thus, according to agenda setting theory, the media has the ability to direct attention to certain issues, to make them inevitable for public discussion. This is reiterated by McCombs and Shaw 1972 cited in Aina [51] assert that in choosing and displaying news, editors, news room staff and broadcasters play an important part in shaping political reality. Readers, learn not only about a given issue, but also how much importance to attach to that issue from the amount of information in a news story and its position. Also, empirical findings of Nwodu and Ezeoke [39] in a study on the evaluation of press coverage of children's and women's right, reveal that that $87.4 \%$ of the stories on women's and children's rights were found in the inside pages of the newspapers leaving insignificant $9.2 \%$ and $3.4 \%$ respectively for the front and back pages. This concurs with the findings of this study.

According to the agenda setting theory The Nation and Daily Trust direct their readers' attention to issues of corruption for public discussion. This indicates that readers learn not only about a given 
issue, but also how much importance to attach to that issue from the amount of information in a news story and its position.

Framing is the selection of some aspects of a perceived reality and make them more salient in a communication text, in such a way as to promote a particular problem definition, causal interpretation, moral evaluation, and treatment recommendation for the item described. It is the process of inclusion and exclusion [41,42]. This study indicates that The Nation and Daily Trust newspapers report corruption issues in positive direction (83\%). sustained coverage on issues of corruption by these dailies draws the attention of the public on such issues thereby placing it on the minds of the audience hence directing the minds of the audience on such issues as important. This implies that when the media frames corrupt people as unpatriotic and selfish, the public tend to regard them in same manner. Framing is concerned primarily with the manner of presentation of such issues.

Another component of Agenda Setting Theory is priming. Priming refers to the media tendency of giving more prominence to certain public issues. This component explains objective three of the study which sought to find out the prominence newspapers gives to issues of corruption in Nigeria. The findings of the study indicate that the sampled newspapers cover issues of corruption with prominence. This therefore justifies the propositions of the theory. In newspapers, the prominent stories appear on the front pages and starting pages inside. The finding that most stories appear on front pages and inside pages shows the prominence the issues of corruption have received.

Dike [52] in Bolu [53] rightly noted that, there is an increase in the coverage of corruption articles by the media but articles are concentrated more on the inside pages of newspapers and space allotment to corruption articles. This is indicative of the fact that majority of these articles occupied one-quarter page of the newspapers. This however dissents from the findings of this study in part as this study indicate that there are issues of corruption reported on the front pages constituted $80(20 \%)$ items by the selected dallies within the period under study. Dike [52] further opined that, it is necessary to place the reportage of corruption articles on the front burner of Nigeria newspapers agenda giving the pervasiveness of the problem in the country and that effort should be intensified by journalists in the area writing of editorials on corruption. This is required to raise a virile social movement against corruption in the country [54].

\section{Conclusion}

Corruption is identified as a long standing clog to the progress and development of the nation. Almost every government that come into power in Nigeria identifies corruption as an excuse for non - performance and poor service delivery to the citizenry. The Muhammadu Buhari administration on assumption of office frowned at corruption out rightly. This was clearly figured out from his body language he had zero tolerance for it. He demonstrated this will by swinging into action to fight the menace immediately by revamping the efforts of anti-corruption agencies in the country to indict arrest, prosecute and recover all looted and misappropriated funds by public officers.

Based on the findings of this study, precisely the study found that issues on corruption were reported frequently. The Nation and Daily Trust newspapers report on corruption mainly in the inside pages; the study found that issues of corruption reported by selected dailies were mostly positive. It is evident that the mass media have been supportive of the ongoing fight against corruption in Nigeria.
The selected newspapers played their expected public roles as agenda setters. These newspapers published and prominently displayed more reports on corruption issues like they mostly do on politics, sports, business, foreign affairs, entertainment, etc., corruption issues were clearly reported.

The mass media as important tools for the dissemination of information for public consumption are strategically knit into the efforts of fighting corruption particularly because of their traditional roles. The frequency, prominence and manner in which reports are presented by the mass media on corruption bothers on the importance the public attach to such issues thus setting agenda. The study found out that the selected dailies have played their role by frequently reporting on issues of corruption and supporting the ongoing fight on corruption by the present Buhari administration. The mass media are through news reports, features editorials and letters to the editor have covered corruption and expose such practices and persons who engage in it in a manner that the public sees them as selfish and unpatriotic citizens of the nation by presenting the reports in a positive direction i.e., in support of the ongoing fight by the Buhari administration.

Media play key roles in investigating allegations of impropriety in public affairs, expose corruption and corrupt practices. These roles become even more important when existing political institutions are weak and inefficient in ensuring accountability of public servant. Credible media, therefore, exercise strong influence over the public and play an important part in revealing improper and unfair administrative actions and corruption

Most of news stories were straight news, backed up with pictures to complement the stories. Most of the items were straight news which indicates that the selected dailies published these stories and reports just as they happen with little or no much detail. Investigations on reasons why things happen and opinions of people behind the happenings must be sought to add flesh to the story and make it more detailed.

\section{Recommendations}

This study has established that the mass media play their roles as expected being socially responsible institutions as identified earlier. This study therefore recommends the following:

1. There is need for in-depth coverage on corruption. There are two layers of investigative reporting: routine check of facts and in-depth. The second layer, may prove difficult but is the most desired to uncover and document facts and activities that were before then unknown to the public. The mass media should not rely solely on reports of happenings around issues of corruption but should through investigative journalism burst and uncover nefarious corrupt practices by government and public officials as provided by Section 22 of the 1999 Constitution of the Federal Republic of Nigeria.

2. Journalists and media practitioners should themselves desist from engaging in corrupt practices while discharging their duties. They should see themselves as ideally positioned to check such excesses and not participate in same. In their watchdog roles to the society, they should sniff out corruption and bark where it exists and not be blindfolded by rewards and gratification that end up influencing the manner of reporting resulting to prejudiced, sensational and editorialized reports.

3. It is also imperative for the mass media to dedicate more space and airtime to reporting on corruption in almost every style i.e., 
Citation: Edmond L, Wilson F (2018) An Assessment of Media Coverage of Anti-Corruption Campaigns by the Buhari Administation in 2016: A Study of the Nation and Daily Trust Newspaper. J Mass Communicat Journalism 8: 376. doi: 10.4172/2165-7912.1000376

Page 15 of 16

features, opinion, columns and letters and editorials which will enrich their coverage thereby making reports more balanced with the opinion of people, reactions and counter reactions of the public and not just one sided reporting in the form of straight news.

4. Follow-ups on stories as they unfold and routine checks on facts should be made a priority by the mass media. Oftentimes only the first two or three events around an issue is reported, the media fails to pursue and report such stories to their logical conclusion hence leaving their audience midway into such developments and helplessly in want of details.

5. The mass media in Nigeria should dedicate more space at the front and back pages of their editions to issues of corruption as these lies on the front burner of the interest of majority of Nigerians. The front and back pages are regarded as the most important pages of the newspaper hence greater importance are accorded to stories placed there by the public.

\section{References}

1. Agbese D (2008) Nigeria their Nigeria. Lagos: Newswatch Books Limited.

2. Nigerian Press Council (2016) Nigerian Press Council website.

3. Smith $\mathrm{CH}$ (2006) Prepared statement on Nigeria's struggle with corruption before the Subcommittee on Africa, Global Human Rights and International Operations of the Committee on International Relations, United States House of Representatives $109^{\text {th }}$ Congress Hearing, 2nd Session, May 18.

4. Arian A (1966) Voting and ideology in Israel. Midwest Journal of Political Science 10: 265-287.

5. Rose-Ackerman S (1999) Corruption and Governance: causes, consequences and reform. Cambridge University Press, pp. 266.

6. Smith DJ (2007) A culture of corruption: Everyday deception and popular discontent in Nigeria. United Kingdom: Princeton University Press, 296.

7. Stapenhurst R (2000) The media's role in curbing corruption. Washington DC World Bank Institute.

8. Coronel S (2009) Corruption and the watchdog role of the news media. Public Sentinel: News Media \& Governance Reform. The World Bank: Washington DC.

9. Centre for Democracy and Governance (1999) The role of media in democracy: A strategic approach. Washington, D.C: USAID.

10. Gambo D (2002) Reporting conflict for television: The editor's perspective. In Pate UA editor. Introduction to conflict reporting in Nigeria. Lagos: Friedrich Ebert Stiftung.

11. Mudashir I, Krishi M, Salau A (2017) Buhari's anti-corruption bill scales Senate's hurdle. Abuja: Daily Trust.

12. Boadu SO (1981) Mass media and modernization: An assessment of theoretical problems. Journal of Black Studies 12: 193-200.

13. Onabajo F (2007) Perception of Radio and Television Evangelism by Nigerian Youths. Babcock Journal of Mass Communication 1: 95-103.

14. McLeod DM, Detenber BH (2006) Framing effects of television news coverage of social protest. Journal of Communication 49: 3-23.

15. Wattenberg M (1982) From parties to candidate: Examining the role of the media. Public Opinion Quarterly 46: 216-227

16. Schramm W (1964) Mass Media and National Development : the role of information in the developing countries. Stanford (California): Stanford University Press.

17. McNelly JT (1966) Mass communication and the climate for modernization in Latin America. Journal of Inter-American Studies 8: 345-357.

18. Rajak SJ (2014) The role of media to fight against corruption. Inter J Curr Res 6: 7576-758

19. Vogl F (1999) Curbing corruption: The media's work. Recommendations for Action, Transparency International Working Paper, presented at the $9^{\text {th }}$ IACC.
20. Ahrend R (2002) Press Freedom, Human Capital, and Corruption. DELTA Working Paper No. 2002-11, 36.

21. Brunetti A, Weder B (2003) A free press is bad news for corruption. J Public Econ 87: 1801-1824.

22. Suphachalasai S (2005) Bureaucratic corruption and mass media. Environmental economy and policy Research Discussion Paper Series Number 05.2005, University of Cambridge, 32

23. Djankov S (2001) Who owns the media? Policy Research working paper 2620 , World Bank

24. Fiske J (1990) "Ethnosemiotics," Cultural Studies 4: 85-100.

25. Akinfeleye RA (2003) Fourth estate of the realm or fourth estate of the wreck: Imperative of social responsibility of the press. Lagos: University of Lagos Press.

26. McNair B (1995) An introduction to political communication. London: Routledge

27. Okosun A (2014) Overheating the Nigerian Polity: Possible consequences of an Ethno-Political War. Nigerian Village Square.

28. Geer GJ (1998) Campaigns, party competitions and political advertising. In Geer, GJ editors. Political and Party Politics. Baltimore and London: John Hopkins University Press.

29. Lerner D, Wilber $S$ (1967) Communication and change in the developing countries. Honolulu: East-West Centre Press.

30. Makoa $F(2000)$ Voters and the politics of elections in Lesotho: (Explaining voting behaviour in the 1998 General Election), Phase 1. AAPS Occasional Paper Series. 4, $(2$.

31. Ngoa NS (2012) Agenda setting: A theory in process. In: Ekeanyawu NT, Ngoa NS, Sobowale IA editors. Critique and Application of Communication Theories. Otta: Covenant University Press.

32. Iroja P (2017) EFCC's lack of diligent Prosecution Sustains Corruption in Nigeria.

33. Ekpo C, Chime J, Enor F (2016) The irony of Nigeria's fight against corruption: an appraisal of President Muhammadu Buhari's first eight months in office. International Journal of History and Philosophical Research 4: 61-73.

34. White T (1973) The making of the President 1972. New York: Bantan.

35. McCombs M, Ghanem I (2001) The convergence of Agenda Setting and Framing." In: Reese, SD, Gandy OH, Grant AE, editors., Framing Public Life: Perspectives on media and our understanding of the social world. Mahwah, $\mathrm{NJ}$ : Erlbaum.

36. Oheneaboagye M (2017) Criticism of Agenda Setting Theory

37. Akagbosu LR, Omoruyi GE (2003) The media and the population policy: A Study of Print Media Reports from January 1988 to May 1989. In: Ikechukwu E. Nwosu editror. Polimedia: Media and Politics in Nigeria. Enugu: ACCE \& Prime Targets 297-306.

38. Galadima JD, Enighe JM (2001) The press in Nigerian politics: A historica analysis of issues and pattern of news coverage. The Nigerian Journal of Communication 1: 62-74.

39. Nwodu LC, Ezeok CB (2013) An evaluation of press coverage of children's and women's rights in Nigeria. Higher Education of Social Science 4: 41-51.

40. Ndolo IS (2009) Rebranding, Re-positioning or Repairing Nigeria. Pape Presented at Annual General Meeting of The Association of Advertising Practitioners of Nigeria (AAPN) Held at Nike Lake Resort, Enugu, p.1-19.

41. Entman RM (1993) Framing toward clarification of a fractured paradigm Journal of Communication 43: 51-58.

42. Peng Z (2008) Framing the Anti-War Protests in the Global Village: A Comparative Study of Newspaper Coverage in Three Countries. The International Communication Gazette 70: 361-377.

43. Kerlinger F, Lee B (2000) Foundations of behavioural research. New York: Harcourt College Publishers.

44. Berger AA (2008) Media and communications research methods. London: Sage Publication Inc.

45. Wimmer R, Dominick J (2000) Mass media research: An introduction. ( $9^{\text {th }}$ edn.) Belmont: Wadsworth Company. 
Citation: Edmond L, Wilson F (2018) An Assessment of Media Coverage of Anti-Corruption Campaigns by the Buhari Administation in 2016: A Study of the Nation and Daily Trust Newspaper. J Mass Communicat Journalism 8: 376. doi: 10.4172/2165-7912.1000376

Page 16 of 16

46. Babbie E, Benaquisto L (2002) Fundamentals of social research. Scarborough: Thomson/Nelson.

47. Stempel G (1981) Readability of six kinds of content in newspapers. Newspaper Research Journal 3: 32-37.

48. Nwana O (1981) Introduction to education research for student teachers. Ibadan: Heinemann Educational Books, pp. 343.

49. Asika N (2010) Research methodology in the behavioural sciences. Ikeja: Longman Nigeria Plc.
50. Babbie E (2010) The practice of social research. Wadsworth: Cengage Learning.

51. Aina S (2003) Anatomy of communication. Abeokuta: Julian publisher

52. Dike VE (2008) Corruption in Nigeria: a new paradigm for effective control.

53. Bolu I (2016) The anti-corruption legal framework and its effect on Nigeria's development. SPA Ajibade \& Co. Lagos: Nigeria.

54. World Bank (1997) Helping countries combat corruption: The role of the World Bank: World Bank Institute/Washington, DC. 